\title{
FINANCIAL LITERACY: THE IMPACT ON THE PROFITABILITY OF THE SMES IN KUCHING
}

\author{
Shafinah Rahim* \\ Universiti Malaysia Sarawak \\ Vinod Raj Balan \\ Universiti Malaysia Sarawak
}

\begin{abstract}
This study aims at investigating the financial knowledge, financial behaviour and the attitude towards finance amongst on small medium entrepreneurs (SMEs) in Kuching. More specifically on how these powerful factors affect the profitability on fast growing business enterprises in largest city in the Borneo Island over the last decade. The research takes a descriptive approach fitting its underlying pursue and draws interesting conclusions with over $75 \%$ response rate. Analysis of the data collected clearly reveals that the knowledge of finance in general relates significantly stronger to the bottom line of these business entities relative to the owners' financial attitude and their ensuing behaviour towards financial decision making. Therefore, small medium entrepreneurs are highly recommended to participate in financial education on a regular basis to keep them well informed and equipped with the latest ways of managing the finances of their businesses to ensure better financial planning, execution and monitoring of enterprises that inevitably will lead to increased and sustainable earnings.
\end{abstract}

Keywords: financial, literacy, profitability

Received: 7 February 2020

Accepted: 11 September 2020

\section{INTRODUCTION}

\subsection{Study Background}

The developing acknowledgement of the significance of Small and Medium Enterprises (SMEs) in emerging economies is due its ability to increase value by generating employment, increasing national income, and the reinforcement of purchasing power both domestically and internationally. Despite their size, total contributions of SMEs in Malaysia are far from small. Approximately $98.5 \%$ of all business establishments in Malaysia are SMEs, contributing RM521.7 billion to the nation's gross domestic product in year 2018 (SME Corporation Malaysia, 2020). They currently provide an estimated 5.7 million jobs to almost $70 \%$ of Malaysia's workforce.

- Corresponding author: Shafinah Rahim, Faculty of Economics and Business, UNIMAS, Tel: 082584376; Email: barshafinah@unimas.my 
Interestingly researches studying the importance of financial literacy amongst SME owners and its effect on productivity and business development related organizational collapses and cited it as one of the contributing element of the 2002/2009 economic crisis (Niwaha, Schmidt, \& Tumuramye, 2016). In the homeland, individuals aged between 30-39 years old are found to experience financial distress compared other working age groups (Suhaimi, 2013). In fact, the Finance Minister of Malaysia, stated that a total of 100,610 Malaysians aged between 18 and 44 years old were declared bankrupt (Carvalho, 2019). Evidently, the lack of financial literacy (36\% compared to $59 \%$ in developed countries) is found to be the main factor, according to a study conducted by S\&P Global Literacy Financial in 2014.

Bank Negara Malaysia reports that low and seasonal-income earners are more vulnerable to financial distress and the higher educated individuals do not necessarily demonstrate better financial management. Evidently, this leads one to presume that knowledge of business financial management is equally essential to potential and aspiring small medium entrepreneurs in order to achieve financial growth and stability in the long run. The need to have a proper understanding of the financial workings of the running and reporting of a commercial enterprise (regardless of the size and turnover volume) is critical to the survival more than the success of any profit-oriented business. This explains the sudden growth and intensification of training programmes connected to financial literacy at all levels. Amongst the initiatives in place include the Integration of financial education elements in the school curriculums (by MoE), Finance Carnivals and Train-the-Trainers Programmes for government agencies (BNM), Smart Investment (SC), Retirement Advisory Services (EPF) and the various reach out programmes by national agency for credit management and counselling (AKPK).

\section{LITERATURE REVIEW}

Financial literacy provides an entrepreneur the capacity to make educated financial decisions with respect to cash management and investments related to their businesses. Financial literacy has become an essential skill for SME owners given its significant bearing on the stability and continuity of their respective commercial enterprises. With increased financial understanding, SMEs are in better position to plan their business finances in the long run. The quality of financial decisions relies heavily on knowledge, behaviour and attitude (Felipe, Ceribeli, \& Lana, 2017).

Figure 1: Factors affecting SME Financial Performance

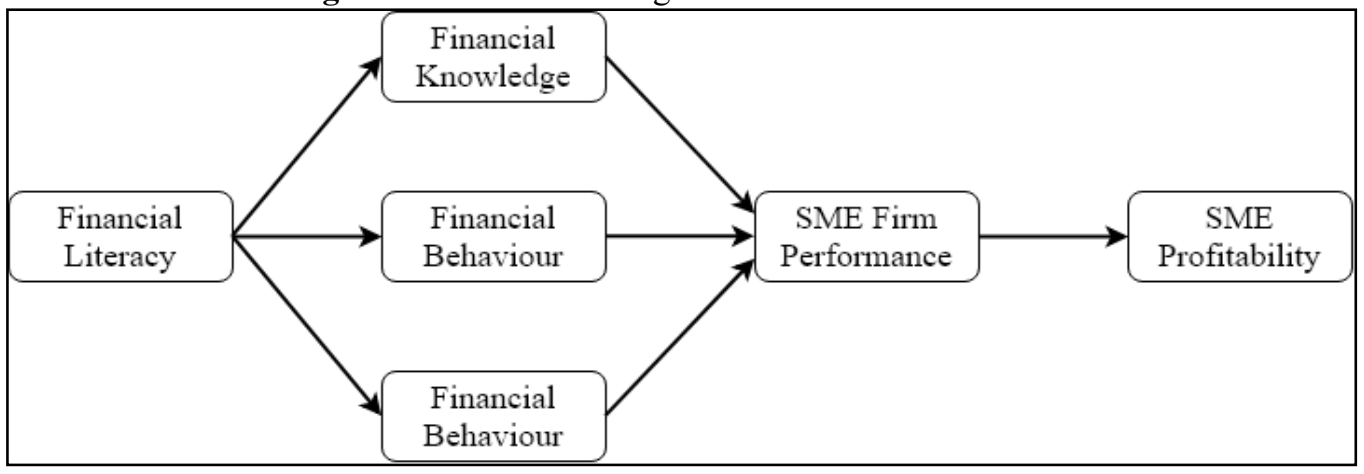




\subsection{Financial Knowledge}

According to Huston (2010), financial knowledge is characterized as the comprehension of key budgetary terms and ideas needed to work on daily basis. Potrich, Vieira and Da-Silva (2016) define it as a particular sort of investment obtained throughout life via the capacity to manage salary, expenses, and savings safely. Whereas, The Organization of Economic Co-Operation and Development (OECD), includes financial knowledge an essential determinant of whether the individual is financially educated, including questions identified with ideas, for example, straightforward and accumulated dividends, risk and return and inflation (OECD INFE, 2011).

It is a typically held contention that enhanced financial information results in more responsible financial conduct and thus, viable monetary choices (Tang, Baker, \& Peter, 2015). Empirical evidences demonstrate that a more elevated amount of information is decidedly identified with people taking part in various "best practice" monetary practices, for example, having a sufficient backup cash, observing credit reports, abstaining from financial account overdrafts, abstaining from revolving debt, owning a devoted retirement account, and having insurance protection (Robb, 2014). Financial education is described as a procedure of enhancing the comprehension of financial products such that the people can build up the capacities and confidence required to make safe and key choices to enhance their monetary prosperity (OECD, 2013).

\subsubsection{Components of Financial Knowledge}

Three interdependent aspects are identified to be relevant to financial knowledge in this work. Brief descriptions of each follows.

\subsubsection{Sources of Finance}

Surprisingly the origin and the law of funding of the capital fund is often neglected by many entrepreneurs once the business begins to operate. Singh and Wasdani (2016), established that funds for micro, small, and medium-sized enterprises (MSMEs) remains a key concern for all partners despite their lack of proper response to take responsibility of its implications. They listed personal savings, loans from friends and family, bank loans, microfinance foundations, and equity funds as the common sources of business financing. An observational examination by Keasey and McGuinness (1990) showed that remotely increased fund was related to greater profit when contrasted with fund raised from within the company. However, the intrinsic constraints of formal sources of funds which has prerequisite for security or an assurance, inflexible policies, high rates of loaning, convoluted techniques, and business owners' inadequate financial knowledge of applicable schemes hinders SMEs at start-up stage from benefiting from the range of schemes targeted to assist this group of self-employers (Singh \& Wasdani, 2016).

\subsubsection{Time Value of Money}

Information and affirmation of the time of money play a vital role in practices of economic decision making (Brigham \& Ehrhardt, 2011). The authors in the subsequent works found the rationale for the adjustment in the value of money over time are systematic factors related to uncertainty, namely inflation. The inclination to spend now or invest for later use, primarily, depends on the purchasing power of cash and the incentives to forgo present consumption. In other words, whether an SME 
should stay liquid, leaving the operating cash in their current account or consider purchasing an asset, is technically contingent upon the present and expected cost of money. Inflation affects the SMEs in terms of the expenses of demand and input as well as their credit availability rates among others. Therefore, they must be aware of the immediate impact of unforeseen adjustments to value of their cash flows (Andonov, Bardong \& Lehnert, 2010).

Martinez (2013) proposed a coordinated strategy to aid in distinguishing the time value of money, perceived to be diverse at various periods of time. The researcher added included that if the planning of and risk associated to cash flows were not observed carefully, financial choices by firms may repudiate the goal of boosting the proprietor's welfare. Burke and Manz (2014) presented an observational evidence to demonstrate the link between financial knowledge and inflation. They discovered that a measure of financial knowledge involves diversification in inflation expectations.

\subsubsection{Diversification}

According to Braakmann \& Wagner (2009), the profitability of production firms with differentiated items are in excess of four times the single-item production firms. Other researchers have also found evidences to support the influence of portfolio management on the long-term profits of businesses. Tarasi, Bolton, Hutt and Walker (2011) described return as the difference in worth of a venture that incorporates growth of assets and the gain of money. Risk or called uncertainty, is the probability of the actual returns of a venture being different from the expected returns. Financially proficient entrepreneurs are in better positions to mitigate their investment risk by distributing cash into different asset types and return time frames. It is highly critical for SMEs to have the basic knowledge of the well-established linear relationship between risk and return of their business investment. Especially when they are facing rationed cash. Being able to justify accepting a higher level of risk for an expected higher return, leaves for room for an SME to venture into newer business opportunities without fear of speculation. This for many budding SMEs has been the single factor determining their continuity.

\subsubsection{Financial Knowledge and Profitability of SMEs}

As eloquently expressed by Robb (2014), in any decision-making process irrespective of the topic, financial literacy is a crucial factor as it is contended to lead to a more successful decision. Financial knowledge is required to create a financial competency measure-to-measure financial market participatory and ability to oversee monetary issues (Lusardi \& Mitchell, 2007). In a later work conducted in The United States in year 2014, these researchers established the following; financial literacy influences essential decisions such as borrowings, savings, investments, and retirement plans. Enterprises of which the managers were less financially literate suffered high transaction expenses, rendering financial literacy a form of an investment in human capital, that advances the growth of wealth. On the contrary, others content financial knowledge in and by itself is inadequate for profit performance regardless of its personal impact on their achievement. Tang et al., (2015) found that accountable financial conduct is originally obtained from parental guidance and self-discipline (known as psychological characteristics) apart from financial literacy in later parts of one's life. A research conducted by Monticone (2010) on the influence of wealth on the attainment of financial literacy showed a weak positive relationship between the two. Evidently, profits did not effectively motivate gaining financial knowledge or vis-a-versa. 


\subsection{Financial Behaviour}

Financial behaviour of individuals can be consistently predicting measures through financial literacy (Hung, Parker, \& Yoong, 2009). Good financial behaviour is argued by (Grohmann, Menkhoff, \& Storck, 2015) to be the ability to diversify assets across multiple types of investment as different investment types are affected by its own specific risk profile.

\subsubsection{Key components of Financial Behaviour}

For the purpose this study, four variables were identified to influence the financial behaviour of small medium entrepreneurs.

\subsubsection{Budgeting \& Planning}

A budget is defined as the master financial document that states the expected contribution form the activities of an organization in terms of expected cash or revenues and expenditures over a certain period of time (Heinle, Ross, \& Saouma, 2014). Naturally, it contributes to the success of a business operation, although micro enterprises paid more attention to cash flows and used budgeting for monitoring purposes alone (Sucuahi, 2013). A research by Kalekye \& Memba, (2015) on the role of financial literacy on profitability of women owned business, found them to be inconsistent in their business financial planning.

\subsubsection{Debt Management}

The ability to prepare, execute and control the range of firm liabilities is referred to as debt management. According to Osei-Assibey, Bokpin \& Twerefou (2010), SMEs are ill equipped with this particular knowledge, often exposing them to the threat of bankruptcy. Despite being aware of the consequences for poor debt servicing, small enterprise owners have a tendency to overlook the benefits of handling their financial obligations to mainly suppliers given the implied cost-free perception that eventually backfires.

\subsubsection{Savings and Investment}

While being financially literate does not guarantee becoming saving conscious or inclined towards investing for the future (Mandell \& Klein, 2009), not being well informed about pension plans have inhibited many from continuing to enjoy the fruits of their labour investment after retirement. In the context of SME owners, knowing their pension options while actively in business allows them to consider the various social security available especially when they are no longer able to contribute their business fulltime. Grohmann et al., (2015) found retirement planning literacy to have a strong positive affect on wealth for private sector retirees.

\subsubsection{Record Keeping}

Record keeping or bookkeeping is an important accounting process that involves recording of all business transactions for sustaining and expanding a business; the process of collecting, organizing, storing and analysing the financial information of an entity to facilitate its day to day operations and preparations of statements, tax returns and internal reports (Ibrahim, 2017). However, Sucuahi 
(2013) showed the preference of SMEs to record transactions manually than to maintain them in the form of ledgers, which eventually results in complexity during tax filing. Works by Lusimbo and Muturi (2016) discovered that most SME managers' lack of interest in book keeping matters is attributed their insufficient knowledge and technical skills in accounting. Hockstein (2016) revealed that SME owners' decision to employ inexperienced administrative staff to avoid high pay qualified accountants is another cause of poor book keeping practices.

\subsubsection{Financial Behaviour and Profitability of SMEs}

Based on the existing research findings and the present trend amongst rapidly growing number of SMEs, it is clear that the financial behaviour of small medium business owners towards their operational decisions remains as a primary determinant of profit making. Lusardi \& Mitchell (2007) concluded that sound financial behaviour led to global competitiveness whilst the opposite runs the business down to closure. An adequate knowledge of sales, profit and wealth maximization is key to responding to financial decisions such as cost saving measures and revenue enhancing strategies (Abiodun, 2016). Studies conducted in different parts of the world indirectly points to the inverse relationship between financial illiteracy and SME profitability.

\subsection{Financial Attitude}

Attitude is characterized as "psychological inclination that is expressed by evaluating a specific substance with a few degree of favour of disfavour by" (Eagle \& Chaiken, 1993). Jodi \& Phyllis (1998) defined financial attitude as the psychological inclination communicated when assessing prescribed financial management practices with some degree of accentuation or difference. Financial attitude is defined as a state of mind, opinion and financial judgment (Pankow, 2012).

\subsubsection{Key Components of Financial Attitude}

Three factors are presumed to influence SMEs mind sets in relations to managing their businesses.

\subsubsection{Risk Taking}

According to Ahmed and Rosylin (2018), understanding a person's attitude towards risk is closely related to the objective of making sense and foreseeing their economic behaviour. Levels of risk tolerance amongst small enterprises reflects the approach to risky ventures with an expected higher than average returns. Ingram \& Thompson (2011) classified risk attitude into the pragmatists (those with belief that the world is uncertain and maximisers (who see the world as self-correcting). A study by Jing, Alhabeeb, Goong-Soog, \& George (2005) on risk-taking behaviour among family business owners found that risky decisions significantly affected consumption of the families and other business partners. In addition, their findings suggested that proposed that family business owners age, race, net worth and influenced attitudes of the business owners risk tolerance. Abiodun (2016) argues that effective entrepreneurs are inherently risk takers. 


\subsubsection{Training}

Carlin and Robinson (2012), explored how financial education changes savings, investment and buyer behaviour and concluded that financial training in fact improved cost-benefit trade-off decisions. A report on SMEs in Kenya indicated that only a small fraction attended formal financial literacy training and as a result suffered from preventable financial losses (International Trade Centre, 2019).

\subsubsection{Social Factors}

The significance of social environment on an individual's financial attitude is an on- going debate by sociologists. Calamato (2010) for example, reported that the capability to make economic decisions, fund management, perspective of economic issues, and future planning is derived through family. Lachance (2014) studied the impact of neighbourhood characteristics on financial literacy and found social learning to be a mechanism to acquire financial knowledge. Those exposed to financially knowledgeable people become more financially knowledgeable small medium entrepreneurs themselves Bucher-Konen and Lusardi (2011). According to Ahmed and Rosylin (2018) financial literacy through social development has critical effects on individuals and business owners. Therefore, the financial attitude of business owners varies depending on their economic backgrounds which ultimately affects the social settings they choose to participate in.

\subsubsection{Financial Attitude and Profitability of SMEs}

A comprehensive study by Ibrahim (2017) observing the effect of financial attitude of Kenyan micro and small enterprise owners and how it affects their profitability found the following: most the respondents have positive attitude towards setting financial targets for the future; business owners are neutral on aspects of time orientation and the influence of social environment on money management skills; the majority of them do not believe in risk prevention as a way of ensuring security of their businesses and they do not have the attitude of attempting to acquire more financial skills through training programs. It concluded that there is a meaningful relationship between profitability and financial attitude of micro and small enterprise owners although evidence indicates financial knowledge not to necessarily translate into profits unless it is applied in decisions and other activities of the business. Another similar work by Esiebugie, Agwa \& Asenge (2018) in Nigeria revealed amongst others, that financial knowledge and attitudes influenced SMEs performance. To this end, one can conclude the profitability prospects of businesses are contingent upon the general position of the owners. A sustainably positive attitude of the actual business operators and decision makers will most likely have a favourable outcome on its success. 


\section{METHODOLOGY}

\subsection{Description of Variables}

\subsubsection{Population \& Sampling Design}

This study focuses on both formal and informal businesses owned by entrepreneurs in Kuching. The sample size estimate consideration is drawn from an accessible population of 10000 entrepreneurs in Kuching, Sarawak (Pei, 2017). It uses random sampling of entrepreneurial population, due to the lack of calculable criteria for grouping or segregating of SME's that area unit closely-held by the entrepreneurs.

\subsubsection{Sample Size}

Cooper and Schindler (2014) defined sample size as the real range of respondents that represents the population that is being studied and carries some relative connection to the population from which it is extracted. The sample size for the current study was determined using this:

$$
N=\frac{N}{1+N(e)^{2}}=\frac{10000}{1+10000(0.05)^{2}}=385
$$

where $\mathrm{N}=$ the size of the population, $\mathrm{n}=$ the sample

\subsubsection{Data Collection}

The standard 5 point Likert scale, 6-page questionnaire survey covering aspects of respondents' demography, financial knowledge, behaviour, attitude and business profitability were distributed and self-administered for a period of 6 weeks. Out of 300 SMEs in Kuching City selected randomly taking into consideration the logistic constraints and possible cooperation of business owners, a total of 235 (with a response rate of $78 \%$ ) complete survey forms then were considered for processing. 


\subsection{Conceptual Framework}

Figure 2: Conceptual Framework

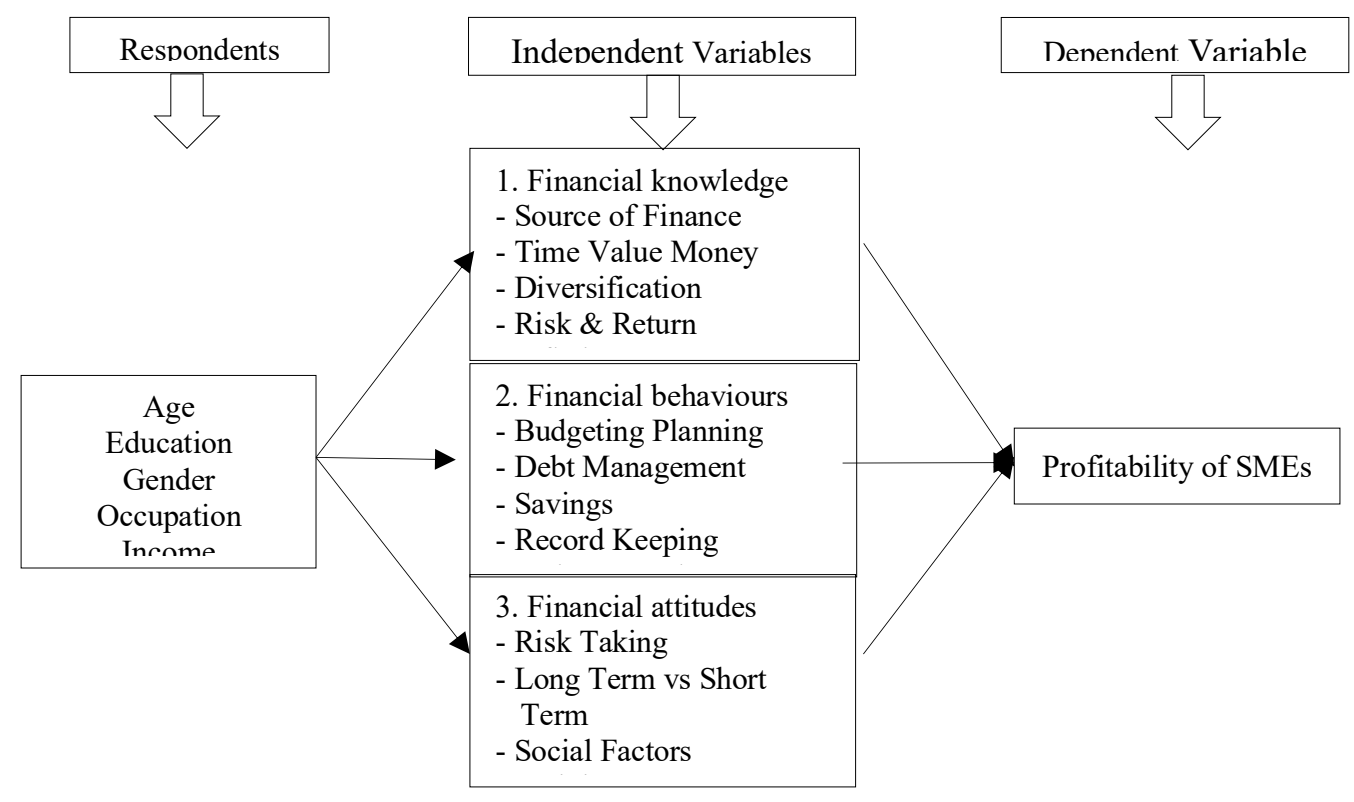

\subsection{Hypotheses Development}

$\mathrm{H}_{1}$ : There is a significant effect of financial knowledge on the profitability of SMEs. $\mathrm{H}_{2}$ : There is a significant effect of financial behaviour on the profitability of SMEs. $\mathrm{H}_{3}$ : There is a significant effect of financial attitude on the profitability of SMEs.

\subsection{Method}

Data collected from survey is generated using interval and ratio scale. Pearson Correlation Coefficient Tests is used to explain the direction, degree of association and the significant level of the variables to test the relationship between the two variables, hence, to reject or accept the hypothesis.

Table 1: Rule of Thumb for Correlation Coefficient

\begin{tabular}{cl}
\hline \hline Size of Correlation & Interpretation \\
\hline 0.90 to 1.00 & Very position or negative \\
0.70 to 0.90 & High Positive or negative \\
0.50 to 0.70 & Moderate positive or negative \\
0.30 to 0.50 & Low positive or negative \\
\hline \hline
\end{tabular}




\section{RESULTS AND DISCUSSION}

\subsection{Profile Summary}

The majority of SMEs were between the age group of 19 and 40 years old, with women taking a lead by $2.2 \%$. Most admit to be (various) first degree holders and business experience of less than 5 years. As expected the largest group of respondents were sole proprietors with almost $50 \%$ being either owners or managers themselves.

Table 2: Respondents' Demographic Profile

\begin{tabular}{cccc}
\hline \hline $\begin{array}{c}\text { Demographic } \\
\text { Variable }\end{array}$ & Category & $\begin{array}{c}\text { Respondents (N=235) } \\
\text { Frequency }\end{array}$ & Percentage (\%) \\
\hline \multirow{2}{*}{ Gender } & Male & 115 & 48.9 \\
& Female & 120 & 51.1 \\
\hline \multirow{2}{*}{ Age } & 18 years old & 18 & 7.7 \\
& $19-30$ years old & 80 & 34.0 \\
& 31-40 years old & 80 & 34.0 \\
Education & 41 and above & 57 & 24.3 \\
Background & Primary School & 18 & 7.7 \\
& Secondary School & 58 & 24.7 \\
& Bachelor's Degree & 127 & 54.0 \\
& Others & 32 & 13.6 \\
\hline \multirow{2}{*}{ Business Association } & Joint Venture & 44 & 18.7 \\
Type & Cooperative Society & 28 & 11.9 \\
& Private Limited & 33 & 14.0 \\
& Partnership & 48 & 20.4 \\
& Sole Proprietorship & 75 & 31.9 \\
& Others & 7 & 3.0 \\
\hline \multirow{2}{*}{ Business Duration } & Less than 1 year & 43 & 18.3 \\
& 2-5 years & 87 & 37.0 \\
& 6-10 years & 70 & 29.8 \\
Position & More than 10 years & 35 & 14.9 \\
\hline \hline & Owner & 115 & 48.9 \\
& Manager & 116 & 49.4 \\
\hline
\end{tabular}

\subsection{Financial Literacy}

\subsubsection{Financial Knowledge}

Nearly half of the SMEs relied on bank loans for their source of business capital, with limited familiarity to alternative forms of savings which had a bearing on their investment choices. Also there was an indication of a lack of awareness of financial and business diversification. 
Table 3: Financial Knowledge

\begin{tabular}{lccc}
\hline \hline \multicolumn{1}{c}{ Variable } & Category & Frequency & $\mathbf{\%}$ \\
\hline & Personal Savings & 20 & 8.5 \\
Source of Capital & Borrowing from family \& friends & 29 & 12.3 \\
& Micro-finance institutions & 10 & 4.3 \\
& Loan from Banks & 109 & 46.4 \\
& Others & 67 & 28.5 \\
\hline \multirow{4}{*}{ Current Form of Saving } & Bank Account & 96 & 40.9 \\
& Mutual Fund & 72 & 30.6 \\
& Property & 56 & 23.8 \\
& None & 11 & 4.7 \\
\hline \multirow{4}{*}{ Safer Investment Option } & One investment or business & 22 & 9.4 \\
& Various businesses & 24 & 10.2 \\
& Neither & 83 & 35.3 \\
& Expand current business & 95 & 40.4 \\
& Do not know & 11 & 4.7 \\
\hline Assets with Highest RoR & Savings in Bank & 62 & 26.4 \\
& Stocks & 17 & 7.2 \\
& Unit Trust & 44 & 18.7 \\
& Property & 99 & 42.1 \\
& Do not know & 13 & 5.5 \\
\hline Unit Trust Investment after 5 years & Buy more unit share & 102 & 43.4 \\
& Balf of the actual share you bought & 87 & 37.0 \\
& It depends on certain factors & 28 & 11.9 \\
\hline An investment in stock with a high & Do not know & 12 & 2.6 \\
& True & 112 & 47.7 \\
\hline \hline
\end{tabular}

\subsubsection{Financial Behaviour}

Table 4: Budget

\begin{tabular}{lccc}
\hline \hline Variable & Category & Frequency & $\%$ \\
I have planned the & Strongly Disagree & 10 & 4.3 \\
financial objectives of my & Disagree & 21 & 8.9 \\
business & Agree & 85 & 36.2 \\
& Strongly Agree & 119 & 50.6 \\
\hline In managing my & Strongly Disagree & 8 & 3.4 \\
expenses, my long-term & Disagree & 17 & 7.2 \\
financial analysis & Agree & 86 & 36.6 \\
influences my business. & Strongly Agree & 124 & 52.8 \\
\hline \multirow{2}{*}{ I track my expenses } & Strongly Disagree & 4 & 1.7 \\
regularly on a weekly or & Disagree & 12 & 5.1 \\
monthly basis. & Agree & 76 & 32.3 \\
& Strongly Agree & 143 & 60.9 \\
\hline \hline
\end{tabular}


Remarkably, more than $85 \%$ of the SME owners and managers confess to have set their financial targets for the businesses, concurrently admitting to the importance of financial analysis to managing their expenses.

Table 5: Debt Management

\begin{tabular}{lccc}
\hline \multicolumn{1}{c}{ Variable } & Category & Frequency & \% \\
\hline \multirow{2}{*}{ My debt management } & Strongly Disagree & 4 & 1.7 \\
skills enable me to & Disagree & 13 & 5.5 \\
finance the business. & Agree & 75 & 31.9 \\
& Strongly Agree & 143 & 60.9 \\
\hline I will be charged & Strongly Disagree & 2 & 0.9 \\
interest when repaying & Disagree & 12 & 5.1 \\
my loans after the & Agree & 86 & 36.6 \\
billing date. & Strongly Agree & 135 & 57.4 \\
\hline \multirow{2}{*}{ I can access my } & Strongly Disagree & 2 & 0.9 \\
finance at a minimum & Disagree & 15 & 6.4 \\
cost. & Agree & 75 & 31.9 \\
& Strongly Agree & 143 & 60.9 \\
\hline \multirow{2}{*}{ I pay off my credit } & Strongly Disagree & 31 & 13.2 \\
card bill in full every & Disagree & 25 & 10.6 \\
month. & Agree & 57 & 24.3 \\
& Strongly Agree & 122 & 51.9 \\
\hline \hline
\end{tabular}

Only a minority (less than 10\%) disagree to the lack of necessary skills, mindfulness of late repayments and access to high cost of financing. However, 23.8\% declared that they do not pay off their credit card bills on time regularly.

Table 6: Saving

\begin{tabular}{lccc}
\hline \hline \multicolumn{1}{c}{ Variable } & Category & Frequency & \% \\
\hline \multirow{2}{*}{ I have a separate saving } & Strongly Disagree & 6 & 2.6 \\
account for my business & Disagree & 10 & 4.3 \\
and personal use & Agree & 85 & 36.2 \\
& Strongly Agree & 134 & 57.0 \\
\hline \multirow{2}{*}{ I save funds for 6 } & Strongly Disagree & 8 & 3.4 \\
months in case of & Disagree & 17 & 7.2 \\
emergency & Agree & 118 & 50.2 \\
& Strongly Agree & 92 & 39.1 \\
\hline I plan to use my savings & Strongly Disagree & 14 & 6.0 \\
for future business & Disagree & 18 & 7.7 \\
needs & Agree & 106 & 45.1 \\
& Strongly Agree & 97 & 41.3 \\
\hline My current state of & Strongly Disagree & 16 & 6.8 \\
personal saving makes & Disagree & 35 & 14.9 \\
me feel guilty or & Agree & 84 & 35.7 \\
anxious. & Strongly Agree & 100 & 42.6 \\
\hline \hline
\end{tabular}


Overall the SMEs show a healthy bill in terms of their business saving habits. The only concern is of the $78.3 \%$ sharing their discomfort with regards to their personal savings which may have an impact on their business in the occurrence of emergencies.

Table 7: Record Keeping

\begin{tabular}{lccc}
\hline \hline \multicolumn{1}{c}{ Variable } & Category & Frequency & \% \\
\hline \multirow{2}{*}{ I have enough knowledge on } & Strongly Disagree & 10 & 4.3 \\
how to balance and maintain & Disagree & 36 & 15.3 \\
my business ledger accounts & Agree & 108 & 46.0 \\
& Strongly Agree & 81 & 34.5 \\
\hline \multirow{2}{*}{ I prepare my business income } & Strongly Disagree & 7 & 3.0 \\
statement and balance sheet on & Disagree & 23 & 9.8 \\
my own & Agree & 86 & 36.6 \\
& Strongly Agree & 119 & 50.6 \\
\hline I can perform financial analysis & Strongly Disagree & 36 & 15.3 \\
on business statements (gross & Disagree & 38 & 16.2 \\
profit margin, net profit margin, & Agree & 67 & 28.5 \\
current ratio) & Strongly Agree & 94 & 40.0 \\
\hline \multirow{2}{*}{ My business decisions are } & Strongly Disagree & 3 & 1.3 \\
influenced by information from & Disagree & 17 & 7.2 \\
financial statements. & Agree & 90 & 38.3 \\
\hline \hline
\end{tabular}

\subsubsection{Financial Attitude}

Table 8: Training and Risk

\begin{tabular}{lccc}
\hline \multicolumn{1}{c}{ Variable } & Category & Frequency & \% \\
\hline I have attended a & Strongly Disagree & 4 & 1.7 \\
financial literacy & Disagree & 20 & 8.5 \\
program. & Agree & 92 & 39.1 \\
& Strongly Agree & 119 & 50.6 \\
\hline All my short-term & Strongly Disagree & 6 & 2.6 \\
decisions are impacted & Disagree & 16 & 6.8 \\
by my long-term goal & Agree & 92 & 39.1 \\
decision. & Strongly Agree & 121 & 51.5 \\
\hline \multirow{2}{*}{ Taking a risky } & Strongly Disagree & 8 & 3.4 \\
investment will add & Disagree & 19 & 8.1 \\
value to my returns & Agree & 116 & 49.4 \\
& Strongly Agree & 92 & 39.1 \\
\hline \multirow{2}{*}{ I have learnt how to } & Strongly Disagree & 16 & 6.8 \\
select a strategic & Disagree & 35 & 14.9 \\
location for business & Agree & 84 & 35.7 \\
\hline & Strongly Agree & 100 & 42.6 \\
I prefer investing than & Strongly Disagree & 10 & 4.3 \\
spending & Disagree & 36 & 15.3 \\
& Agree & 108 & 46.0 \\
\hline
\end{tabular}




\begin{tabular}{lccc}
\hline \hline \multicolumn{1}{c}{ Variable } & Category & Frequency & \% \\
\hline \multirow{2}{*}{ It is really important to } & Strongly Disagree & 36 & 15.3 \\
plan for emergencies & Disagree & 38 & 16.2 \\
in business & Agree & 67 & 28.5 \\
& Strongly Agree & 94 & 40.0 \\
\hline \hline
\end{tabular}

Generally, the responses lean towards openness to learning and making informed business decisions through considerable experience with formal preparation. SMEs appear to embrace calculated risks, with more than $80 \%$ indicating preference to investment than consumption spending.

\subsection{SME Profitability}

Table 9: On Profitability

\begin{tabular}{lccc}
\hline \hline \multicolumn{1}{c}{ Variable } & Category & Frequency & \% \\
\hline How does your actual net & Less than I expect & 54 & 23.0 \\
profits differ from the & Same as I expect & 93 & 39.6 \\
estimated profits? & More than I expected & 88 & 37.4 \\
\hline \multirow{2}{*}{ Which range shows your } & Less than RM 5,000 & 19 & 8.1 \\
typical business annual & RM 5,001 to RM 20,000 & 39 & 16.6 \\
sales? & RM 20,001 to RM 50,000 & 122 & 51.9 \\
& More than RM 50,000 & 55 & 23.4 \\
\hline \multirow{2}{*}{ What is your profit margin } & $10 \%$ and below & 9 & 3.8 \\
(in \%) & $11 \%$ to 30\% & 42 & 17.9 \\
& $31 \%$ to 50\% & 126 & 53.6 \\
\hline \hline
\end{tabular}

Almost a quarter of the SME owners declare that their actual profits are below their targets with a $25 \%$ of them (suspected the same group) to report yearly sales of less than RM20k.In contrast, the majority of the respondents maintain to an average market profit margin between $31 \%-50 \%$.

\subsection{Discussion of Results}

The Cronbach's alpha coefficient for all variables exceeded the acceptable level of 0.70 satisfying the reliability and validity of the measurement model.

Table 10: Results of Reliability Test

\begin{tabular}{cc}
\hline \hline Variables & Cronbach's $\boldsymbol{\alpha}$ \\
\hline Financial Knowledge & 0.745 \\
Financial Behaviour & 0.779 \\
Financial Attitude & 0.764 \\
\hline \hline
\end{tabular}

The Pearson's Chi-Square Test indicated a statistically significant relationship between independent variables and SME profitability. 
Table 11: Summary of Pearson's chi-square test results

\begin{tabular}{lccc}
\hline \multicolumn{1}{c}{ Independent Variables } & Chi-Square & df & Significance \\
\hline Financial Knowledge & 933.224 & 176 & 0.000 \\
Financial Behaviour & 452.413 & 385 & 0.010 \\
Financial Attitude & 250.751 & 187 & 0.001 \\
\hline \hline
\end{tabular}

Note: The dependent variable is the respondent's profitability of their SME in Kuching.

Hypotheses testing rejected all three null hypotheses of this research, as the p-values scored less than the alpha value of 0.05 . Thus confirming the following:

$\mathbf{H}_{1}$ : There is a significant effect of financial knowledge on the profitability of SMEs.

$\mathbf{H}_{2}$ : There is a significant effect of financial behaviour on the profitability of SMEs.

$\mathbf{H}_{3}$ : There is a significant effect of financial attitude on the profitability of SMEs.

The normality test found that both the independent and dependent variables were not normally distributed with the significance value for each independent variable of less than the alpha value of 0.05 .

Table 12: Summary of Normality Test

\begin{tabular}{|c|c|c|c|c|c|c|}
\hline \multirow{2}{*}{$\begin{array}{c}\text { Independent } \\
\text { Variables }\end{array}$} & \multicolumn{3}{|c|}{ Kolmogorov-Smirnova } & \multicolumn{3}{|c|}{ "Shapiro-Wilk } \\
\hline & Statistics & $\mathrm{df}$ & Sig. & Statistics & $\mathrm{df}$ & Sig. \\
\hline $\begin{array}{l}\text { Financial } \\
\text { Knowledge }\end{array}$ & 0.169 & 235 & 0.000 & 0.906 & 235 & 0.000 \\
\hline $\begin{array}{l}\text { Financial } \\
\text { Behaviour }\end{array}$ & 0.095 & 235 & 0.000 & 0.964 & 235 & 0.000 \\
\hline $\begin{array}{l}\text { Financial } \\
\text { Attitude }\end{array}$ & 0.100 & 235 & 0.000 & 0.975 & 235 & 0.000 \\
\hline
\end{tabular}

The Kendall's tau_b test was conducted to determine the strength of the association that exists between the two variables used in the questionnaire.

Table 13: Summary of Kendall's tau b Test Results

\begin{tabular}{lcc}
\hline \multicolumn{1}{c}{ Independent Variables } & Kendall's tau_b & Sig. (2-tailed) \\
\hline Financial Knowledge** & 0.619 & 0.000 \\
Financial Behaviour** & 0.241 & 0.000 \\
Financial Attitude** & 0.149 & 0.003 \\
\hline \hline
\end{tabular}

Note: ** Correlation is significant at the 0.01 level (2-tailed). Test of normality was conducted and both variables are not normally distributed. The dependent variable is respondent's SMEs profitability.

\subsubsection{Financial Knowledge and Respondents' SME Profitability}

H1: There is a significant effect of financial knowledge on the profitability of SMEs. 
Based on Table 11, the Pearson's chi-square for financial knowledge has a value of 933.224 with a $p$-value of 0.000 , lower than the alpha value of $0.05(p<0.05)$. Therefore, the null hypothesis that there is no relationship between financial knowledge and respondents' SME profitability is rejected.

Findings in Table 4.13 shows that the relationship between financial knowledge and SME profitability is significant at $1 \%$. It's $p$-value of 0.0000 is lower than 0.05 . The Kendall's tau_b correlation coefficient between financial knowledge and SME profitability of 0.619, suggests a moderate positive linear relationship between the two.

\subsubsection{Financial Behaviour and Respondents' SME Profitability}

\section{H2: There is a significant effect of financial behaviour on the profitability of SMES.}

The Pearson's chi-square for financial behaviour in Table 11 shows a value of 452.413 with pvalue of $0.010(\mathrm{p}<0.05)$. The null hypothesis that there is no relationship between financial behaviour and SME profitability is rejected.

The p-value of the coefficient for financial behaviour is in Table 4.13 is lower than the alpha value of $0.05(\mathrm{p}<0.05)$. This implies that the relationship between financial behaviour and SME profitability is significant at $1 \%$. The Kendall's tau_b correlation coefficient of 0.241 , suggests a positive weak linear relationship between the two variables.

\subsubsection{Financial Attitude and Respondents' SME Profitability}

\section{H3: There is a significant effect of financial attitude on the profitability of SMEs.}

The Pearson's chi-square value for financial attitude is 250.751 with $\mathrm{p}$-value of $0.001(\mathrm{p}<0.05)$. Therefore, the null hypothesis there is no relationship between financial attitude respondents' SME profitability can be rejected.

The p-value of the coefficient for financial attitude (0.003) is lower than the p-value of 0.05. 0.003 (Table 4.13) at 15 significance level. The Kendall's tau_b correlation coefficient of 0.149 between financial attitude and SME profitability suggests is a weak positive linear relationship between the two varaibles.

\section{CONCLUSION \& RECOMMENDATION}

The purpose of study on the influence of financial literacy on the profitability of SMEs in Kuching was duly achieved, with the findings attesting to the relevance of financial knowledge, behaviour and attitude amongst small medium entrepreneurs towards the bottom line of their business performance. In short at least four inferences can be made here.

Firstly, the link between financial knowledge and the corresponding behaviour is one that deserves further attention from enterprise owners, irrespective of the size of their business. Learning through experience alone can be destructive, especially when matters relating to financial management, 
namely regulation on taxation and investment portfolio options change frequently in a dynamic market.

Then, the puzzling effects of attitude on behaviour is unquestionably one of the most unsettling topic in behavioural psychology. Fazio and Roskos-Ewoldsen (2005) in their recent contribution to a textbook chapter serves as a reference to the complexity involved in predicting behaviour from the observation of a certain type of attitude by rational human being.

In the case of SMEs, it is evident that having a positive attitude towards managing finances, is not a guarantee that the business operators behaved in accordance. The next points to the forces at work, if and when heightened financial awareness leads to meaningful financial reactions.

Provision and access to financial workshops catered for SMEs have been on the rise, with government agencies and even NGOs committed to assist single parents, and house bound caregivers to make a decent a decent living through low overhead self-operated businesses. However, the effectiveness of such support systems principally depends on these SMEs' dedication and willpower to succeed. Thus making their internal drive critical in ensuring the numerous schemes in place function as desired. Lastly, the composite effect of financial literacy on the earning capacity of micro enterprises requires further investigation based on business goals, nature of trade, location, product type and services. SMEs in different industries are expected to reflect varying degree of interest and responsibility towards their respective businesses. Specifics will undeniably shed light onto how financial literacy can be advantageous for SMEs' survival and stability.

\section{REFERENCES}

Abiodun, A. (2016). Financial literacy and SME firm performance. International Journal of Research Studies in Management, 5(1), 31-43.

Ahmed, M. \& Rosylin, M.Y. (2018). Financial Literacy and Behavioral Finance: Conceptual Foundations and Research Issues. Journal of Economics and Sustainable Development, 9(10), 81-89.

Andonov, A., Bardong, F. \& Lehnert, T. (2010). TIPS, Inflation Expectations, and the Financial Crisis. Financial Analysts Journal, 66(6), 27-39. Retrieved from https://ssrn.com/abstract=1722356

Braakmann, N. \& Wagner, J. (2009). Product Differentiation and Profitability in German Manufacturing Firms. Working Paper Series in Economics No. 15. Germany: University of Luneburg.

Brigham, E. \& Ehrhardt, M. (2010). Financial Management: Theory and Practice. South-Western Cengage Learning.

Bucher-Koenan, T., \& Lusardi, A. (2011). Financial literacy and retirement planning: How wellprepared are German households? Retrieved from

http://www.voxeu.org/article/financial

-illiteracy-new-evidence-germany

Burke, M. A., \& Manz, M. (2014). Economic literacy and inflation expectations: Evidence from a laboratory experiment. Journal of Money, Credit and Banking, 46(7), 1421-1456. doi: 10.1111/jmcb. 12144 
Calamato, M. P. (2010). Learning financial literacy in the family (Unpublished master's thesis). San Jose State University, California. Retrieved from https://scholarworks.sjsu.edu/etd_theses/3849

Carlin, B. I., \& Robinson, D. T. (2012). What Does Financial Literacy Training Teach Us? The Journal of Economic Education, 43(3), 235-247. doi:10.1080/00220485.2012.686385

Carvalho, M. (2019, March 4). Guan Eng: Low financial literacy among Malaysian youth contributing to high bankruptcy rates. The Star. Retrieved https:/www.thestar.com.my/news/nation/2019/03/04/guan-eng-low-financial-literacyamong-malaysian-youth-contributing-to-high-bankruptcy-rates/

Cooper, D. R. \& Schindler, P. S. (2014). Business Research Methods (12 ${ }^{\text {nd }}$ ed). New York: Mcgrraw-Hill Education

Cooper, D. R., Schindler, P. S., \& Sun, J. (2006). Business research methods $\left(11^{\text {st }}\right.$ ed). New York: McGraw-Hill Irwin.

Eagly, A. H., \& Chaiken, S. (1993). The psychology of attitudes. Orlando, US: Harcourt Brace Jovanovich College Publishers.

Esiebugie,U., Agwa,T.R. \& Asenge,L.E. (2018). Financial literacy and performance of small and medium enterprises in Benue state, Nigeria. International Journal of Economics, Business, and Management Research, 2(4), 65-79.

Fazio, R.H., \& Roskos-Ewoldsen, D. (2005). Acting as We Feel: When and How Attitudes Guide Behaviour. In Brock T. C., \& Green, M. C. (Eds.), Persuasion: Psychological Insights and Perspectives, (2 ${ }^{\text {nd }}$ ed, pp. 41-62). Thousand Oaks, CA: Sage Publications.

Felipe, I. J., Ceribeli, H. B., \& Lana, T. Q. (2017). Investigating the level of financial literacy of university students. Journal of Administration, Accounting and Economics (RACE), 16(3), 845-866. doi: http://dx.doi.org/10.18593/race.v16i3.13458

Grohmann, A., Menkhoff, L., \& Storck, J. (2015). Financial Literacy and Financial Behavior. DIW Economic Bulletin, 5, 406-426.

Heinle, M. S., Ross, N., \& Saouma, R. E. (2014). A theory of participative budgeting. The Accounting Review, 89(3), 1025-1050. doi: 10.2308/accr-50686

Hockstein, E. (2016). Identify and verify refugee skills. Engaging with Employers in the Hiring of Refugees. Geneva: OECD, UNHCR.

Hung, A., Parker, A. M., \& Yoong, J. (2009). Defining and measuring financial literacy. RAND Working Paper Series WR-708. Retrieved from http://dx.doi.org/10.2139/ssrn.1498674

Huston, S. J. (2010). Measuring financial literacy. The Journal of Consumer Affairs, 44(2), 296316. doi: https://doi.org/10.1111/j.1745-6606.2010.01170.x

Ibrahim, A. H. (2017). The impact of financial literacy on the profitability of micro and small enterprises owned by university students in Kenya: A case study of United States International University-Africa (Unpublished master's thesis). United States International University Africa, Kenya.

Ingram, D. \& Thompson, M. (2011, February). The Changing Seasons of Risk Attitudes. Society of Actuaries, 8(1), 21-24.

International Trade Centre. (2019). Promoting SME Competitiveness in Kenya: Targeted solutions for inclusive growth Kenya. Geneva: International Trade Centre.

Jing, J. X, Alhabeed, M. J., Hong, G. S. \& Haynes, G. (2005). Attitude toward Risk and RiskTaking Behavior of Business-Owning Families. Journal of Consumer Affairs, 35(2), $307-$ 325. 
Jodi L. Parrotta, \& Phyllis J. Johnson. (1998). The impact of financial attitudes and knowledge on financial management and satisfaction of recently married individuals. Association for Financial Counselling and Planning, 9(2), 59-75.

Kalekye, P. \& Memba, F. (2015). The Role of Financial Literacy on the Profitability of Women Owned Enterprises in Kitui Town, Kitui County, Kenya. International Journal of Science and Research, 4(6), 2360-2365.

Keasey, K., \& McGuinness, P. (1990). Small new firms and the return to alternative sources of $\begin{array}{llll}\text { finance. Small } \quad \text { Business 213-222. } & \text { Economics, }\end{array}$ doi:https://doi.org/10.1007/BF00389529

Lachance, M. E. (2014). Financial literacy and neighborhood effects. The Journal of Consumer Affairs, 48(2), 251-273. doi: https://doi.org/10.1111/joca.12024

Lusardi, A., \& Mitchell, O. S. (2007). Financial literacy and retirement preparedness: Evidence and implications for financial education. Business Economics, 42(1), 35-44. doi: https://doi.org/10.2145/20070104

Lusimbo, E. N., \& Muturi, W. (2016). Financial literacy and the growth of small enterprises in Kenya: A case of Kakamega Central Sub-County, Kenya. International Journal of Economics, Commerce and Management, 4(6), 828-845. Retrieved from http://ijecm.co.uk/wp-content/uploads/2016/06/4649.pdf

Mandell, L., \& Klein, L. S. (2009). The impact of financial literacy education on subsequent financial behavior. Journal of Financial Counseling and Planning, 20(1), 15-24. Retrieved from https://ssrn.com/abstract=2224231

Martinez, V. (2013). Time value of money made simple: A graphic teaching method. Journal of Financial Education, 39(1/2), 96-117. Retrieved from https://www.jstor.org/stable/41948701

Monticone, C. (2010). How much does wealth matter in the acquisition of financial literacy? The Journal of Consumer Affairs, 44(2), 403-422.

Niwaha, M., Schmidt, O., \& Tumuramye, P. (2016). Financial Literacy and Development Experimental Insights from Rural Micro- and Small Entrepreneurs (MSEs) in Western Uganda. International Journal of Development Research, 6(2), 6758-6764.

Organisation for Economic Co-operation and Developement (OECD). (2013). Advancing national strategies for financial education. Russia's G20 Presidency; OECD. Retrieved from http://www.oecd.org/finance/financial-education/advancing-national-strategies-forfinancial-education.htm

Organisation for Economic Co-operation and Developemnt INFE (OECD INF). (2011). Measuring Financial Literacy: Core Questionnaire in Measuring Financial Literacy: Questionnaire and Guidance Notes for conducting an Internationally Comparable Survey of Financial literacy. Paris: OECD.

Osei-Assibey, E., Bokpin, G. A. and Twerefou, D. K. (2010). The Microenterprise and Financing Preference in Ghana: Is There a Hierarchical Preference Ordering? SSRN eLibrary. Retrieved from https://papers.ssrn.com/sol3/papers.cfm?abstract_id=1612071

Pankow, D. (2012). Financial Values, Attitudes and Goals. Retrieved from https://www.ag.ndsu.edu/pubs/yf/fammgmt/fs591.pdf

Pei, G. P. (2017, Oct 21). Sarawakians expecting more focus on SME, eco-tourism, environment in state 2018 budget. New Straits Times. Retrieved from https://www.nst.com.my/news /nation/2017/10/293438/sarawakians-expecting-more-focus-sme-eco-tourismenvironment-state-2018 
Potrich, A. C., Vieira, K. M., \& Mendes-Da-Silva, W. (2016). Development of a financial literacy model for university students. Management Research Review, 39(3), 356-376. doi:10.1108/MRR-06-2014-0143

Robb, C. A. (2014). The personal financial knowledge conundrum. Journal of Financial Service Professionals, 69-73.

Singh, C., and K. P. Wasdani. (2016). Finance for Micro, Small, and Medium-Sized Enterprises in India: Sources and Challenges. ADBI Working Paper 581. Tokyo: Asian Development Bank Institute. Available: http://www.adb.org/publications/finance-micro-smallandmedium-sized-enterprises-india-sources-and-challenges/

SME Corporation Malaysia (2020). SME Annual Report 2018/2019: Entrepreneurship Driving SMEs. Retrieved from https://www.smecorp.gov.my/images/SMEAR/SMEAR2018 2019/final/english/SME\%20AR\%20-\%20English\%20-\%20All\%20Chapter\%20Final\%2 024Jan2020.pdf

Sucuahi, W. T. (2013). Determinants of financial literacy of micro entrepreneurs in Davao City. International Journal of Accounting Research, I(1), 44-51.

Suhami, A. (2013). Financial Literacy in Malaysia: Issues and Staus Update. International Seminar on Financial Education and Retirement Savings. Kuala Lumpur: BNM.

Tang, N., Baker, A., \& Peter, P. C. (2015). Investigating the Disconnect between Financial Knowledge and Behavior: The Role of Parental Influence and Psychological Characteristics in Responsible Financial Behaviors among Young Adults. The Journal of Consumer Affairs, 376-406.

Tarasi, C., Bolton, r. Hutt, M. \& Walker, B. (2011). Balancing Risk and Return in a Customer Portfolio. Journal in Marketing, 75(3), 1-17. 